Vol. 5, No. 01; 2021

ISSN: $2581-3366$

\title{
Somatic and Psychological Consequences of Covid-19 on Healthcare Professionals and Its Effects on Healthcare Delivery in a Teaching Hospital in Khyber Pakhtunkhwa, Pakistan
}

\author{
Carl Hermann Dino Steinmetz ${ }^{1}$, Faiz U1 Haq ${ }^{2,3}$, Saeed Ur Rehman ${ }^{4}$, Muhammad Romman ${ }^{5}$, and, \\ Mahendra $\mathrm{Pal}^{6}$ \\ ${ }^{1}$ Expats and Immigrants B.V., Amsterdam, the Netherlands \\ Mail: carl@expats-immigrants.com \\ ${ }^{2}$ Department of Microbiology, University of Health Sciences Lahore, Pakistan \\ For Correspondence: +923155747346 \\ ${ }^{3}$ Centre for Biotechnology and Microbiology University of Swat, Pakistan \\ ${ }^{4}$ Department of Nursing University of Health Sciences Lahore, Pakistan \\ ${ }^{5}$ Pharmacognosy laboratory, University of Chitral Pakistan \\ ${ }^{6}$ Narayan Consultancy on Veterinary Public Health and Microbiology, Gujarat, India.
}

doi: $10.51505 /$ ijmshr.2021.5113

URL: http://dx.doi.org/10.51505/ijmshr.2021.5113

\begin{abstract}
This is a descriptive framework study (Peng et al. 2008) of COVID-19 pandemic viral disease among healthcare professionals at the Timergara Teaching Hospital Dir Khyber Pakhtunkhwa, Pakistan, its physical and psychological consequences for them and its effects on the local healthcare delivery. Only healthcare professionals with a positive RT-PCR (reverse transcription polymerase chain reaction) test were included in this study. The theory of opportunity was used because the virus is supposed to seek opportunities to multiply. Some support has come to this theory. The most startling outcome is that COVID-19 care has supplanted 'normal' patient care. In addition, we believe that at the Timergara Teaching Hospital Dir Khyber Pakhtunkhwa all protective measures (including PPE) against the transmission of COVID-19 particles to healthcare professionals should be critically examined for their preventive effect. The third conclusion is that more attention should be paid to the psychological impact of COVID-19 on healthcare professionals (via victim assistance and EMDR therapy) and preventive and proactive care (e.g. through stress inoculation).
\end{abstract}

Keywords: Healthcare workers, COVID-19, RT-PCR test, preventive and curative measures, dropout of healthcare professionals, influence on healthcare, descriptive framework. opportunity theory. 


\section{International Journal of Medical Science and Health Research}

Vol. 5, No. 01; 2021

ISSN: $2581-3366$

\section{Background}

At the end of 2019, a cluster of pneumonia cases of unknown aetiology associated with a new coronavirus emerged in Wuhan city, China (Zhu et al., 2020).

"It is thanks to the 'hack' of two brave virologists - a Chinese and a British Australian - that the SARS-CoV-2 coronavirus pandemic has not claimed many more victims worldwide. On 11 January of this year, at 2 a.m. Dutch time, virologist Eddie Holmes of the University of Sydney posted the genetic code of 29.903 letters of the virus on the public website of virological.org. That genetic blueprint of the virus has been deciphered by Zhang Yongzhen, a virologist at Fudan University in Shanghai, with whom Holmes has worked for years. Against the will of the Chinese government, Zhang and Holmes decide that the world should know immediately what new virus has broken out in Wuhan (NRC, 2020)."

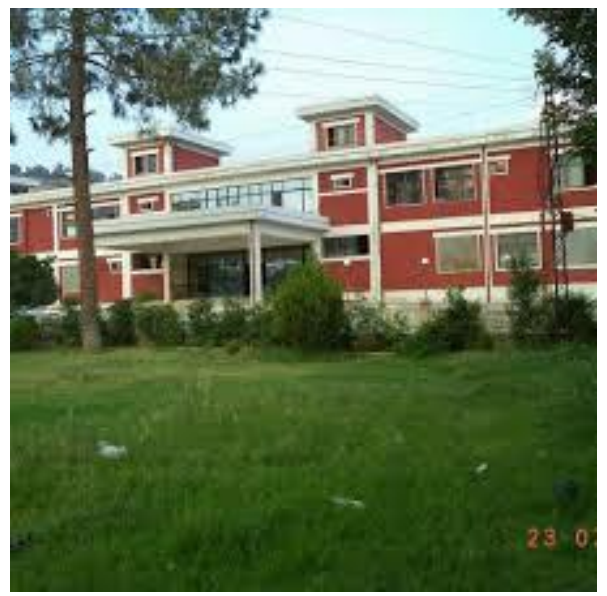

Figure 1: YDA DHQ Hospital Timergara (source Facebook) ${ }^{1}$

Incidentally, the COVID-19 virus that has flooded the world is one of the many mutants of the original Wuhan virus. As recently as the 20th of December 2020, a new even more contagious variant (20201212/01) has emerged in England (Keulemans, 2020). "BBC News (06-01-2021) further identifies a South African mutant of the COVID-19 virus. All viruses naturally mutate ${ }^{2}$ over time, and Sars-CoV-2 is no exception." An Oxford study ${ }^{3}$ shows that the corona virus has been with us for some time, but was looking for an opportunity to strike:

\footnotetext{
${ }^{1}$ https://www.google.com/search?q=Timergara+Teaching+Hospital\&client=firefox-bd\&sxsrf=ALeKk02sKwOKSOXezOGhTqPX900qTCffng:1609861345912\&tbm=isch\&source=iu\&ictx=1\&fir=MX6Zik7uy 94sxM\%252CktFsRYQ1CxxwvM\%252C \&vet=1\&usg=K CPRcesNX6IWdvlsrelpiX5azEO8\%3D\&sa=X\&ved=2ahUKEwi Wg6TtkIXuAhWa7aQKHc5DDVoQuqIBMBN6BAgcEAM\&biw=1920\&bih=910\#imgrc=MX6Zik7uy94sxM\&imgdii=RW5bQ08vfIPTM

${ }^{2}$ https://www.bbc.com/news/science-environment-55404988

${ }^{3}$ https://www.sciencefocus.com/news/the-coronavirus-may-not-have-originated-in-china-says-oxford-professor/
} 


\section{International Journal of Medical Science and Health Research}

Vol. 5, No. 01; 2021

ISSN: 2581-3366

"The coronavirus may have been lying dormant across the world until emerging under favourable environmental conditions, rather than originating in China, an expert has claimed."

After it was found that this virus had been detected in Wuhan, the new corona virus-2019 was said to be a serious acute respiratory corona virus-2 (SARS-CoV-2) (see viral taxonomist (Haq et al., 2020).

"Common clinical spectrum of the disease includes high fever, dry or productive cough, shortness, and difficulty of breathing, sore throat, general weakness, myalgia, and chills (Pal, et al., 2020)."

By the $28^{\text {th }}$ of January 2021 (14:02, Dutch time), approximately 100.977 .927 million people worldwide were infected by SARS-CoV-2 and 2.177.418 died (WHO, 2020 $)$. According to both an Austrian and a German dark number study, these figures are the tip of the iceberg" and must be multiplied by a factor between 4 and 8 in order to see the reality (Steinmetz, 2020).

SARS-CoV-2 is distributed in different ways, drop by drop (small and big) and as a cloud of mini-drops (Ghinai et al., 2020). This last way of spreading through a fog of very small drops is common when intubating patients. COVID-19 asymptomatic disease among healthcare workers could be a powerful source of transmission, increasing the burden of disease. Primary hospital care staff have a high risk of infection due to close personal contacts with COVID-19 patients (Black et al., 2020).

In order to reduce or prevent the nosocomial transmission of SARS-CoV-2 and other respiratory viruses (Verbeek et al., 2020), the proper use of Personal Protective Equipment (PPE) by healthcare professionals is urgently needed. When COVID-19 started in Khyber PakhtunkhwaPakistan, there was a worldwide shortage of masks, face shields, coats and breathing apparatus. This was due to global disruptions in the supply chain and demand far exceeding supply. This affects the work of healthcare professionals (Nguyen et al., 2020). N-95 face shields and respirators (an N95 mask offers more protection than a surgical mask does because it filters out both large and small particles when the wearer inhales) - of which $50 \%$ originate from China are among the designated protective equipment for healthcare professionals. They can only be used once. Because of the shortages, disinfection protocols have been drawn up by the hospital to inactivate SARS-CoV-2 on N-95 respirators (Fischer et al., 2020).

SARS-CoV broke out at the end of February 2003 (possibly originated in China, WHOpublication $^{5}$ ) and spread to 4 other countries), MERS in Saudi Arabia (probably Jordan) in 2012 (with a large outbreak in the Republic of Korea in $2015^{6}$ ) and now the COVID-19 pandemic that again threatens the lives of healthcare professionals. The number of people infected or dying is

${ }^{4}$ https://coronavirus.jhu.edu/map.html

${ }^{5}$ https://www.who.int/health-topics/severe-acute-respiratory-syndrome\#tab=tab 1

${ }^{6}$ https://www.cdc.gov/coronavirus/mers/about/index.html

www.ijmshr.com

Page 122 


\section{International Journal of Medical Science and Health Research}

Vol. 5, No. 01; 2021

ISSN: 2581-3366

phenomenal. Healthcare professionals (and also medical students) are being asked to take care of these patients. This puts them in great danger and puts their own lives at risk by looking after citizens (Jones, 2020; Elkholy et al., 2020).

"Millions of people worldwide are staying at home to minimise the transmission of severe acute respiratory syndrome coronavirus 2 , but healthcare professionals are preparing to do just the opposite. They go to clinics and hospitals risking their lives to be infected by COVID-19 virus. Figures from China's National Health Commission show that more than 3.300 healthcare professionals have been infected as of early March 2020 and, according to local media, by the end of February 2020 at least 22 had died. In Italy, 20\% of responding health-care workers were infected, and some have died. Reports from medical staff describe physical and mental exhaustion, the torment of difficult triage decisions, and the pain of losing patients and colleagues, all in addition to the infection risk (Lancet, 2020)."

Public health measures are essential to reduce risks to healthcare professionals. In practice, this means identifying, preventing and combating emerging sources of infection (Kandel et al., 2020). This is virtually impossible for low and middle-income countries because of the limited or non-existent protection resources (Kandel et al., 2020).

Ziarati et al. (2020) are launching a plea in which they indicate that healthcare professionals should be trained in a healthy lifestyle.

"A healthy lifestyle includes not only eating nutritious food but also practicing of good habits like walking and regular exercises, maintaining good emotional and mental health and taking adequate rest. Therefore, the responsibility of the individuals during the COVID-19 pandemic lies in making an effort to choose a healthy lifestyle, and take optimum rest. Her article and that of her colleagues provide a glimpse of how good health and a healthy immune system can be achieved by working on our self-immunity and by following a healthy lifestyle (Parisa et al., 2020).”

COVID-19 has disproportionately affected the healthcare system in Pakistan. Disruption of the healthcare system may lead to an exorbitant reduction in regular care and also to unexpected COVID-19 outbreaks because the care cannot adequately respond to possible new infections (Chandir et al., 2020). COVID-19 also has important economic consequences for healthcare as a whole, both curative and preventive. The spread of downgrading of care, as mentioned, has consequences for the quality of patient care in the hospital, such as treatment when a cardiovascular emergency occurs. In short, as a result of this long period of 'intimate' exposure to COVID-19 patients and their relatives and the associated workload, hospital staff are at increased risk of health problems (Carter et al., 2020).

The Timergara Teaching Hospital gave a high priority to addressing the health risks of healthcare professionals during the COVID-19 pandemic (Lancet, 2020; Wang et al., 2020). How this worked out among healthcare professionals during the first wave of COVID-19 at the Timergarahee Training Hospital is the topic reported on in this article. It also looked at the 


\section{International Journal of Medical Science and Health Research}

Vol. 5, No. 01; 2021

ISSN: 2581-3366

effects of COVID-19 on the healthcare delivery system as a whole. Although we cannot look inside the heads of the CEOs of this hospital, it is reasonable to assume that this investigation was started because the hospital is worried about being able to provide their 'normal' services in the future due to the loss of their staff (health professionals). Especially now it has become known that even more dangerous (more contagious and possibly deadly) mutants of COVID-19 virus are around

\section{Postulate}

An important assumption is checked in this article. We would like to postulate that healthcare professionals are at considerable risk of a serious acute infection by a acute respiratory coronavirus-2 (SARS-CoV-2) syndrome which may also cause them to fall ill, physical and psychological. COVID-19 has a disproportionately disruptive effect on health care. To date, little data is known about COVID-19 among healthcare professionals (and medical students as volunteers), the physical and psychological consequences for them and its impact on the healthcare system. The results of a study on COVID-19 and healthcare professionals, its consequences for professionals and its impact on Pakistan's health system in Khyber Pakhtunkhwa-Pakistan are presented in this article.

\section{Theory}

The COVID-19 virus has no face. It is invisible to the layman's eye. COVID-19 is omnipresent. Even so, worldwide an immeasurable number of people are already ill -both physical and psychologically- and deceased. In this theoretical part of this article we try to estimate how likely that is for healthcare professionals in a hospital. We do this because we actually know the following. Not everyone is infected with the virus and of all the infected people, very few die. The simple conclusion is that a large proportion of infected people recover. But that is not true. A significant proportion remain in a so-called physical and psychological twilight zone of socalled recovery for a long time.

Joseph et al. (2016) claim that the 59 million healthcare professionals with a huge workload, because many vacancies are not filled, are not at all as healthy as is thought. First and foremost, they run many risks of illness as a result of their work:

"In a report published by the WHO, the disease burden caused by percutaneous sharps injuries among healthcare professionals was found to be three million per year. Moreover, $40 \%$ of hepatitis B, $40 \%$ of hepatitis C, and $4.4 \%$ of HIV among healthcare professionals were due to needle stick injuries. It is very unfortunate that approximately 1.000 healthcare professionals die annually from occupational HIV, which can and should have been prevented. Despite this, almost $80 \%$ of healthcare professionals remain unimmunized (against Hepatitis B) in many parts of the world."

Furthermore, according to Joseph et al. (2016), healthcare professionals are not 'holy beans':

"Several studies have found that healthcare professionals fare no better than the general population when it comes to non-communicable diseases such as diabetes and 


\section{International Journal of Medical Science and Health Research}

Vol. 5, No. 01; 2021

ISSN: 2581-3366

hypertension, as well as cardiovascular diseases. They continue to smoke, consume alcohol, eat junk food, sleep erratically, and remain obese with little physical exercise despite knowing the health risks that they pose. This shows that we do not always "practice what we preach'."

A Pakistani study of psychological complaints among female doctors in the Pakistani healthcare system, especially anxiety, comes up with the following statement:

"Our results also suggest that female physicians suffer more from anxiety associated with COVID-19 than their male counterparts. There may be various explanations for this. The first explanation refers to gender stereotypes, as women as carers and emphatic beings experience more anxiety and stress by empathising with their patients and further the uncertainty of the recovery of their patients. Second, in a patriarchal society like Pakistan, women (mothers, daughters and wives) are in practice responsible for looking after the household, children and family members when they come home from work. Women therefore cannot isolate themselves after returning from work, with the result that their household and families are at risk of being infected. Both factors contribute to significantly higher attrition rates among female doctors (Mahmood et al., 2021).”

In short, a starting point for this theoretical part on the risks for healthcare professionals due to the COVID-19 virus in respiratory droplets (large, small and particles) via contact, droplet, mist and airborne transmission is, in general, that compared to the 'average' citizen, they are at much higher risk of illness (physical and psychological) and unhealthiness, partly due to their contact with patients and the enormous workload in hospitals.

This can be further enhanced by healthcare professionals working together in the hospital to support and help patients. In order to be able to study these risks, we propose to work with the opportunity theory and, where possible, with routine activity patterns (Steinmetz, 1979). This theory starts with the proposition that:

"Opportunity creates infection and death of healthcare professionals. The most important factors for a high or low risk of infection or death of healthcare professionals by COVID19 are:

1. Attractiveness (for instance healthcare professionals with existing diseases, like diabetes, heart problems and obesity etc.)

2. Proximity (for instance, intimate and close contacts of healthcare professionals with patients and each other etc.)

3. Protection (all safety measures: proactive, preventive and curative)." 


\section{International Journal of Medical Science and Health Research}

Vol. 5, No. 01; 2021

ISSN: 2581-3366

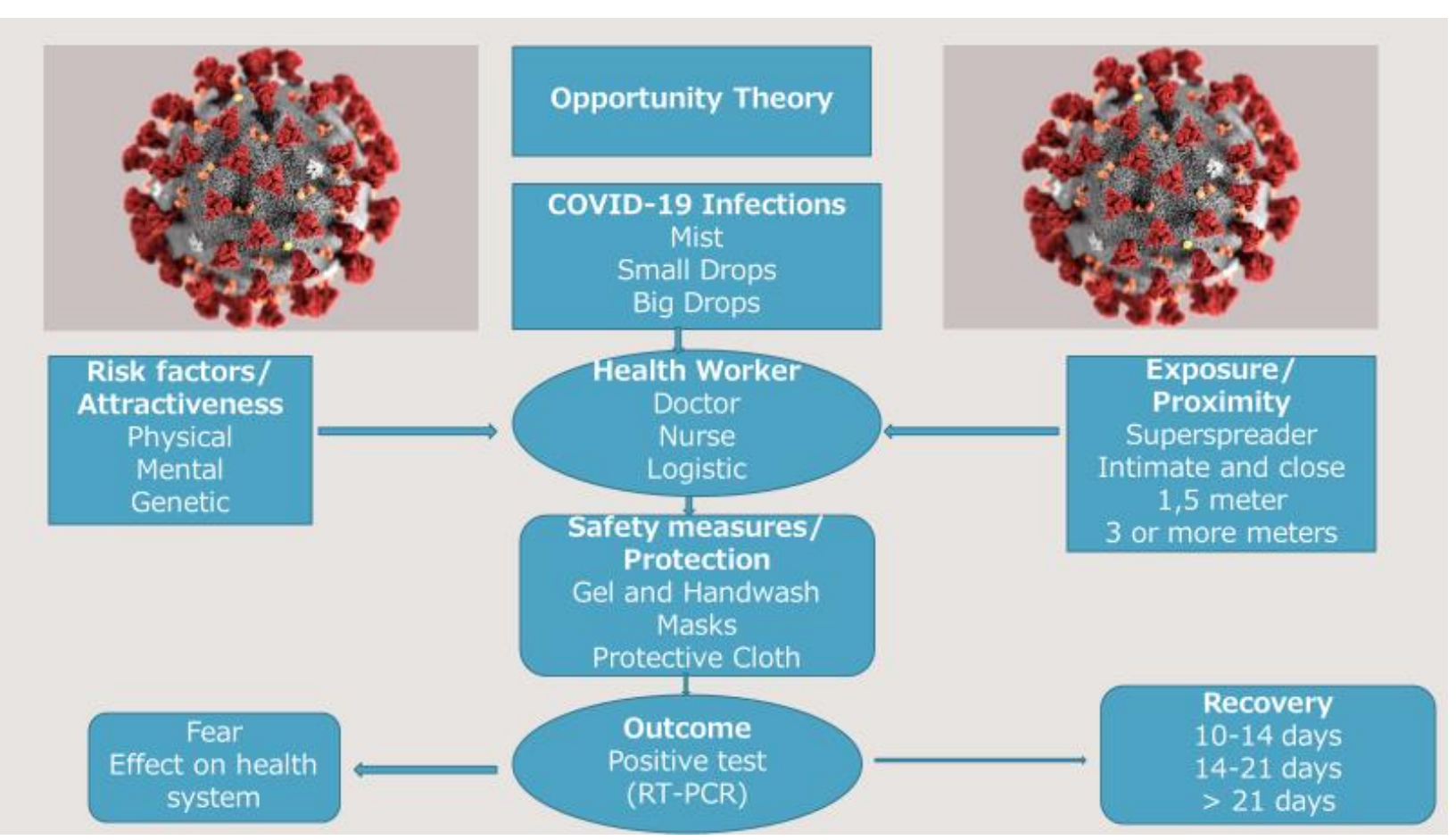

Figure 2:The opportunity theory for COVID-19 and healthcare professionals

\section{Method}

The DHQ Timergara teaching hospital in Khyber Pakhtunkhwa province in Pakistan performed a cross-sectional COVID-19 survey $^{7}$ among healthcare professionals and volunteers (medical students). This hospital was founded in 1965 and updated to a DHQ hospital in 1984 and upgraded to a Category A hospital in 2002-2003. The hospital provides services to a population of 1.45 million people. In total, the hospital has more than 500 beds. The hospital also provides services to people outside the local region, namely people from Upper Dir, District Chitral, District Bajour and irrespective of these local services, Afghan refugees. The total number of medical staff is 93, the nurses 140 and the other operational staff (paramedics and class IV) is 432. The total number of patients/OPD and casualties served by this hospital on an annual base is 505.041 .

\subsection{Study design and participants}

The participants in this study are healthcare professionals with a positive RT-PCR test ${ }^{8}$ for COVID-19 in the period from October 2019 up to and including July 2020. Epidemiological data

\footnotetext{
${ }^{7} \mathrm{~A}$ cross-sectional survey collects data to make inferences about a population of interest (universe) at one point in time. Cross-sectional surveys have been described as snapshots of the populations about which they gather data. ${ }^{8}$ https://www.idsociety.org/covid-19-real-time-learning-network/diagnostics/RT-pcr-testing/: " SARS-CoV-2 RT-PCR detects viral RNA; a positive result is highly specific for the presence of the virus. The sensitivity of these tests is not uniform, and is affected not only by the assay itself, but also the limit of detection, viral inoculum, timing of testing, and sample collection site."
} 


\section{International Journal of Medical Science and Health Research}

Vol. 5, No. 01; 2021

ISSN: 2581-3366

from the respondents were collected through structured interviews ${ }^{9}$. Information was collected on demographic characteristics, symptoms, possible sources of transmission, co-morbidity and anxiety of COVID-19. An estimate was also made of the impact of COVID-19 on this healthcare institute. These infected and sick healthcare professionals by COVID-19 did their work in various departments of the hospital: emergency departments, ICU, CCU, surgical departments, children's departments.

Ethical approval was obtained from the ethics committees (Chief Medical Inspector, Timergara Training Hospital). Written consent was obtained from all participating healthcare professionals for the collection of SARS-CoV-2 related data. In this article we follow the STROBE guidelines for observational studies (Elm, von, et al., 2007).

\subsection{Procedure}

Information obtained through detail questionnaire. Participants in the study were interviewed to determine their demographic characteristics and socio-economic status. Participants were asked about their history of exposure to patients, duration of illness, symptoms of infection and isolation site. The participants were furthermore interviewed about their direct and indirect contacts with patients. In this research doctors, nurses, assistant nurses, nursing students and medical students were included as front line healthcare professionals. Healthcare professionals were asked about PPE (gloves, gowns, goggles, hair cover, and surgical masks) use and their availability. In an additional study, participants were questioned about their co-morbidities, smoking habits, knowledge of COVID-19, anxiety of COVID-19 and administrative support for them. As the hospital had to recruit alternative health workers to fill gaps, a survey was conducted to assess the impact of health workers with COVID-19 on the hospital. The hospital collected data on the admission of new patients in 5 months before the first lockdown and in the first 5 months during the first lockdown.

A quote from one of the doctors of this teaching hospital in Khyber Pakhtunkhwa-Pakistan about COVID-19 is:

"The COVID-19 pandemic was a totally new experience for our hospital, although it was already known at the time that COVID-19 was causing many problems worldwide. The risk of COVID-19 is particularly high for healthcare professionals working in our hospital. I would also like to draw your attention to our feelings of anxiety, depression and, in addition, the sharp increase in working hours, which puts hospital staff at a high risk of absenteeism and burnout on top of the existing physical risks that COVID-19 poses to healthcare professionals. A high rate of infection among health care workers here in Khyber Pakhtunkhwa is creating a situation where doctors are no longer able to take care of their regular patients. Therefore, we have asked the health directorate of our hospital to raise this issue with the health authorities, with the main request being to help us minimise all forms of COVID-19-related fallout among healthcare workers."

${ }^{9}$ Data and questionnaire can be obtained via the contact addresses. 
Vol. 5, No. 01; 2021

ISSN: 2581-3366

\subsection{Structure of variables}

In the following scheme all variables of this research are clustered in main groups.

\begin{tabular}{|c|c|c|c|c|c|}
\hline $\begin{array}{l}\text { Infection } \\
\text { source } \\
(\text { total }=72)\end{array}$ & Independent & Dependent & Prevention & Recovery & Effects \\
\hline $\begin{array}{l}\text { 1. } \begin{array}{l}\text { Hospital } \\
(\mathrm{n}=70 ;\end{array} \\
97 \%) \\
\text { 2. } \begin{array}{l}\text { Others } \\
(\mathrm{n}=2 ; \\
3 \%)\end{array}\end{array}$ & 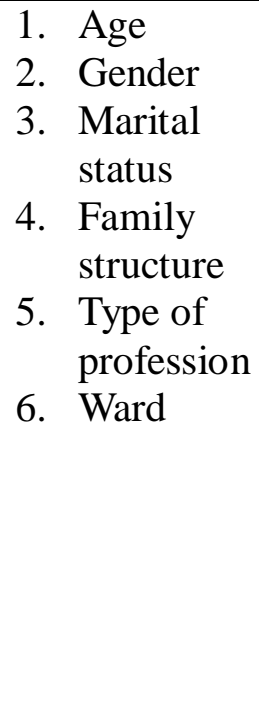 & $\begin{array}{ll}\text { 1. } & \begin{array}{l}\text { Duration } \\
\text { of illness }\end{array} \\
\text { 2. Symptoms } \\
\text { 3. Anxiety } \\
\text { during } \\
\text { COVID } \\
\text { 4. } \text { Comorbidi } \\
\text { ty (yes = } \\
5 ; 7 \%)\end{array}$ & $\begin{array}{ll}\text { 1. } & \text { COVID- } \\
19 \\
\text { session } \\
\text { attended } \\
\text { 2. }\end{array}$ & 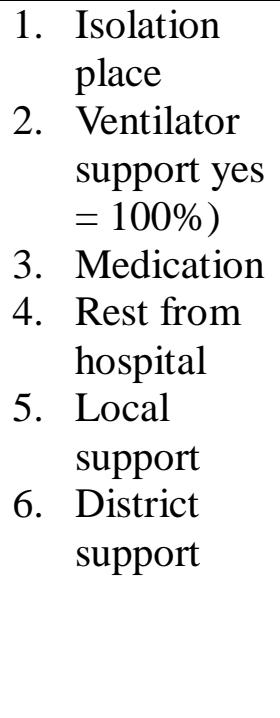 & $\begin{array}{l}\text { 1. Spread to } \\
\text { others } \\
\text { 2. Effect on } \\
\text { Health } \\
\text { system } \\
\text { 3. Feeling } \\
\text { unsafe about } \\
\text { family } \\
\text { 4. Anxiety } \\
\text { after COVID } \\
\text { recovery } \\
\text { 5nxiety of } \\
\text { other from } \\
\text { you after } \\
\text { recovery }\end{array}$ \\
\hline \multicolumn{6}{|c|}{$\begin{array}{l}\text { Long term consequences and giving back: } \\
\text { 1. Antibody status } \\
\text { 2. Donate plasma }\end{array}$} \\
\hline
\end{tabular}

Diagram 1: All research variables

\section{Results}

In this section on the results of the study, the results are reported separately for each main group of variables. In addition, the hospital collected data on the number of patients admitted and/or treated by the hospital.

\subsection{Admission before and during the first lockdown}

Timergara teaching hospital collected data about admission to the different wards five month before and five month during COVID-19. Before lockdown, the period October 2019 up to and including February 2020 was taken. After lockdown, the period March 2020 up to and including July 2020 was considered. This comparison between before and during COVID-19 shows that the hospital accepts fewer patients during the COVID-19 period. The average decrease in the number of registered patients is almost $36 \%$. Relatively high percentages are found in the orthopaedic ward (83\%) and the corona care unit [CCU] (79\%), while relatively low percentages are found in the medical ward $(40 \%)$ and the female surgical ward (53\%). According to the hospital, the decrease in the number of patients is due to the fact that healthcare providers are no longer able to work due to illness and absenteeism caused by COVID-19. The admissions per department are given below. 


\begin{tabular}{|l|l|l|}
\hline Type of ward & $\begin{array}{l}\text { Before Lockdown } \\
\text { (number of } \\
\text { admissions) }\end{array}$ & $\begin{array}{l}\text { During Lockdown } \\
\text { (number of } \\
\text { admissions) }\end{array}$ \\
\hline Medical ward & 864 & $347(40 \%)$ \\
\hline CCU ward & 915 & $721(79 \%)$ \\
\hline Male surgical ward & 411 & $248(60 \%)$ \\
\hline Female surgical ward & 591 & $313(53 \%)$ \\
\hline Orthopaedic ward & 1.113 & $928(83 \%)$ \\
\hline Neurological ward & 615 & $358(58 \%)$ \\
\hline Total & $\mathbf{4 . 5 0 9}$ & $\mathbf{2 . 9 0 5 ( 6 4 \% )}$ \\
\hline
\end{tabular}

Table 1: Type of ward, 5 month before and during first lockdown $($ Chi-square $=117.345 ; \mathrm{df}=5 ;$ and $\mathrm{p}=0,00)$

\subsection{Independent and dependent variables}

Most healthcare professionals in this investigation became infected with COVID-19 at the Timergara Teaching Hospital (97\%), only 3\% became infected elsewhere. In this paragraph several questions will be answered. First of all, what proportion of healthcare personnel divided by type of function has been infected with COVID-19 in this teaching hospital? This question is answered in table 2 .

\begin{tabular}{|l|l|l|}
\hline Functions & $\begin{array}{l}\text { Total } \\
\text { Hospital } \\
\text { Personnel }\end{array}$ & $\begin{array}{l}\text { COVID-19 victims } \\
\text { (positive RT-PCR } \\
\text { test) }\end{array}$ \\
\hline Doctors & $93(14 \%)$ & $\begin{array}{l}18(19 \% / \\
25 \%)\end{array}$ \\
\hline Nurses & $140(21 \%)$ & $\begin{array}{l}42(30 \% / \\
58 \%)\end{array}$ \\
\hline $\begin{array}{l}\text { Paramedics } \\
\text { Other staff }\end{array}$ & $432(65 \%)$ & $\begin{array}{l}\text { Paramedics (7) } \\
\text { Other staff (5) } \\
\text { Total: 12 (3\%/ } \\
\mathbf{1 7 \% )}\end{array}$ \\
\hline $\begin{array}{l}\text { Total } \\
\text { personnel }\end{array}$ & $\mathbf{6 6 5 ( 1 0 0 \% )}$ & $\begin{array}{l}\mathbf{7 2 ( 1 1 \% /} \\
\mathbf{1 0 0 \%})\end{array}$ \\
\hline
\end{tabular}

Table 2: Number of victimized healthcare professionals compared to total hospital population by function

The outcomes are (chi-square 66.95, $\mathrm{df}=2$ and $\mathrm{p}=0.0$ ):

1. $11 \%$ of all healthcare professionals tested positive with an RT-PCR test.

2. Nurses (30\%) are most at risk of COVID-19 and paramedical professions and other staff (3\%) are least at risk. Doctors (19\%) are half as much at risk as nurses. 


\section{International Journal of Medical Science and Health Research}

Vol. 5, No. 01; 2021

ISSN: 2581-3366

An attempt is also being made to sketch the relationships between gender, age and duration of the disease. After all, population studies show that men are ill for longer or more severely than women and that older people are more likely to become ill than young people. The results are shown in table 3.Apart from this, Table 3 also looks at departments with relatively many and few COVID-19 victims.

\begin{tabular}{|c|c|c|c|}
\hline $\begin{array}{l}\text { Gender/age/ } \\
\text { duration of } \\
\text { illness }\end{array}$ & $\begin{array}{l}\text { Frequency } \\
\text { duration of } \\
\text { illness/ } \\
\text { average/ } \\
\text { variance }\end{array}$ & $\begin{array}{l}\text { Total } \\
\text { number of } \\
\text { symptoms/ } \\
\text { average/ } \\
\text { variance }\end{array}$ & Type of ward \\
\hline Female & & & \multirow{9}{*}{$\begin{array}{l}\text { Emergency }(21: 29 \%) \\
\text { ICU (4: 6\%) } \\
\text { CCU (6: } 8 \%) \\
\text { COVID (11: } 15 \%) \\
\text { Medical (4: 6\%) } \\
\text { Surgery (5: 7\%) } \\
\text { Labour-room (14: 19\%) } \\
\text { Operation theatre (7: } 10 \%)\end{array}$} \\
\hline $\begin{array}{l}21-30 \text { years/ } \\
14-21 \text { days }\end{array}$ & $\begin{array}{l}12(60 \%) / \\
1.5 / 0,45\end{array}$ & $\begin{array}{l}39(62 \%) / \\
3,25 / 0,99\end{array}$ & \\
\hline $\begin{array}{l}31-40 \text { years/ } \\
>21 \text { days }\end{array}$ & $\begin{array}{l}8(40 \%) / \\
1,75 / 0,79\end{array}$ & $\begin{array}{l}24(38 \%) / \\
3,00 / 0,86\end{array}$ & \\
\hline $\begin{array}{l}\text { Subtotal } \\
(\mathbf{n}=\mathbf{2 0})\end{array}$ & $\begin{array}{l}20(28 \%) / \\
1,60 / 0,57\end{array}$ & $\begin{array}{l}63(30 \%) / \\
3,15 / 0,87 \\
\end{array}$ & \\
\hline \multicolumn{3}{|l|}{ Male } & \\
\hline $\begin{array}{l}21-30 \text { years/ } \\
10-14 \text { days }\end{array}$ & $\begin{array}{l}12(24 \%) / \\
1,67 / 0,79\end{array}$ & $\begin{array}{l}41(28 \%) / \\
3,42 / 0,81\end{array}$ & \\
\hline $\begin{array}{l}\text { 31-40 years/ } \\
14-21 \text { days }\end{array}$ & $\begin{array}{l}30(55 \%) / \\
1,50 / 0,53\end{array}$ & $\begin{array}{l}80(54 \%) / \\
2,67 / 1,33\end{array}$ & \\
\hline $\begin{array}{l}40 \text { years+ } 1 \\
>21 \text { days }\end{array}$ & $\begin{array}{l}10(19 \%) / \\
1,60 / 0,49\end{array}$ & $\begin{array}{l}26(18 \%) / \\
2,60 / 1,38\end{array}$ & \\
\hline $\begin{array}{l}\text { Subtotal } \\
(\mathbf{n}=\mathbf{5 2})\end{array}$ & $\begin{array}{l}52(72 \%) / \\
1,56 / 0,57\end{array}$ & $\begin{array}{l}147(70 \%) / \\
2,83 / 1,28\end{array}$ & \\
\hline $\begin{array}{l}\text { Total } \\
(\mathrm{n}=72)\end{array}$ & $\begin{array}{l}72 \\
(100 \%) / \\
1,57 / 0,56\end{array}$ & $\begin{array}{l}210 \\
(100 \%) / \\
2,92 / 1,18\end{array}$ & Total (72: 100\%) \\
\hline
\end{tabular}

Table 3: Relations between gender, age, and duration of illness and number of healthcare professionals per wards.

The conclusions drawn on the basis of the data in Table 3 are as follows:

1. Victim prone departments for COVID-19 are emergency, labour room and COVID treatment rooms $\left(\mathrm{X}^{2}=28 ; \mathrm{df}=7 ; \mathrm{p}\right.$-value $\left.=4.333257 \mathrm{e}-7\right)$.

2. There are more male (72\%) than female victims (28\%) among COVID-19 health workers $\left(\mathrm{X}^{2}=7.481 ; \mathrm{df}=1 ; \mathrm{p}\right.$-value $\left.=0.00623\right)$

3. On average, female healthcare professionals $(\overline{\mathbf{x}}=1,60)$ are sick for as long as male healthcare professionals $(\overline{\mathbf{x}}=1,56)$ after they fall ill as a result of COVID-19. 


\section{International Journal of Medical Science and Health Research}

Vol. 5, No. 01; 2021

ISSN: 2581-3366

4. On average, female healthcare professionals have as many COVID-19 symptoms as male healthcare professionals (independent $\mathrm{T}$ test $=1.226 ; \mathrm{df}=702 ; \mathrm{p} \leq 0.20$ ).

Thirdly, it looks at how long the various healthcare professionals in the hospital have been ill and how many symptoms have been associated with this. When calculating the average duration of illness, the number of healthcare professionals who have been ill for 10-14 days $(=1), 14-21$ days $(=2)$ and 21 days or more $(=3)$, was used.

\begin{tabular}{|l|l|l|l|l|}
\hline Functions & $\begin{array}{l}\text { Average } \\
\text { duration } \\
\text { illness }\end{array}$ & $\begin{array}{l}\text { Variance } \\
\text { duration } \\
\text { illness }\end{array}$ & $\begin{array}{l}\text { Average } \\
\text { number } \\
\text { symptoms }\end{array}$ & $\begin{array}{l}\text { Variation } \\
\text { number } \\
\text { symptoms }\end{array}$ \\
\hline Doctor $(\mathrm{n}=18)$ & 1,72 & 0,57 & 3,00 & 0,82 \\
\hline Nurse $(\mathrm{n}=42)$ & 1.38 & 0,33 & 2,74 & 1.17 \\
\hline Paramedics $(\mathrm{n}=7)$ & 2,57 & 0,62 & 3,86 & 2,14 \\
\hline Other staff $(\mathrm{n}=5)$ & 1,60 & 0,80 & 2,80 & 0,20 \\
\hline Total $(\mathbf{n}=\mathbf{7 2})$ & $\mathbf{1 , 5 7}$ & $\mathbf{0 , 5 6}$ & $\mathbf{2 , 9 2}$ & $\mathbf{1 , 1 8}$ \\
\hline
\end{tabular}

Table 4: Functions, duration of illness (average and variance), and number of COVID-19 symptoms (average and variance).

On average, doctors are sick longer than nurses (independent $\mathrm{T}$-test $=1.79 ; \mathrm{df}=58 ; \mathrm{p}=0.05$ ). Doctors and nurses, on the other hand, have as many average COVID-19 symptoms (independent T-test $=0.592 ; \mathrm{df}=58 ; \mathrm{p}>0.09$ ).

The fourth research question is: 'Are there certain healthcare professionals who are more anxious of COVID-19 than other healthcare professionals?'

\begin{tabular}{|l|l|l|}
\hline Functions & $\begin{array}{l}\text { Average anxiety } \\
\text { during COVID- } \\
\mathbf{1 9}\end{array}$ & $\begin{array}{l}\text { Variance anxiety } \\
\text { during COVID- } \\
\mathbf{1 9}\end{array}$ \\
\hline Doctor $(\mathrm{n}=18)$ & 1,389 & 0,252 \\
\hline Nurse $(\mathrm{n}=42)$ & 1,286 & 0,209 \\
\hline Paramedics $(\mathrm{n}=7)$ & 1,000 & 0,000 \\
\hline Other staff $(\mathrm{n}=5)$ & 1,000 & 0,000 \\
\hline Total $(\mathbf{n}=\mathbf{7 2})$ & $\mathbf{1 , 2 6 4}$ & $\mathbf{0 , 1 9 7}$ \\
\hline
\end{tabular}

Table 5: Functions and Average anxiety during COVID-19

During COVID-19 doctors are as afraid as nurses for COVID-19 during COVID-19 (independent T-test $=0,768 ; \mathrm{df}=58 ; \mathrm{p}=0.5$ ).

The fifth research question is: do healthcare professionals from extended families on average have more symptoms than healthcare professionals from nuclear families, and are they also on average sick for longer than healthcare professionals from nuclear families? The underlying 
assumption is that healthcare professionals from extended families at home are more in contact with other family members than healthcare professionals from nuclear families.

\begin{tabular}{|l|l|l|l|l|}
\hline Family structure & $\begin{array}{l}\text { Average } \\
\text { duration of } \\
\text { illness }\end{array}$ & $\begin{array}{l}\text { Variance } \\
\text { duration of } \\
\text { illness }\end{array}$ & $\begin{array}{l}\text { Average } \\
\text { number of } \\
\text { symptoms }\end{array}$ & $\begin{array}{l}\text { Variance } \\
\text { number of } \\
\text { symptoms }\end{array}$ \\
\hline Extended $(\mathrm{n}=42)$ & 1,50 & 0,55 & 2,64 & 1,26 \\
\hline Nuclear $(\mathrm{n}=30)$ & 1,67 & 0,57 & 3,30 & 0,84 \\
\hline Total $(\mathbf{n}=\mathbf{7 2})$ & $\mathbf{1 , 5 7}$ & $\mathbf{0 , 5 6}$ & $\mathbf{2 , 9 2}$ & $\mathbf{1 , 1 8}$ \\
\hline
\end{tabular}

Table 6: Family structure and average number of COVID-19 symptoms

On average, healthcare professionals from nuclear families have more symptoms than healthcare professionals from extended families (independent T-test $=11.38 ; \mathrm{df}=10 ; \mathrm{p}<.001$ ). The same applies to the duration of illness. Healthcare professionals from nuclear families are sick for longer than healthcare professionals from extended families (independent t-test $=4,15$; $\mathrm{df}=10$; $\mathrm{p}<.01)$. In order to understand more of the results in table 6 , we looked at the relationship between age, family structure and whether or not one is married. The results are presented in table 7.

\begin{tabular}{|l|l|l|l|}
\hline $\begin{array}{l}\text { Age/ Family structure } \\
\mathbf{1}=\text { extended; } 2= \\
\text { nuclear) }\end{array}$ & $\begin{array}{l}\text { Marital status: } \\
\text { Married } \\
\text { Frequency } \\
\text { Average }\end{array}$ & $\begin{array}{l}\text { Marital status: } \\
\text { Unmarried } \\
\text { Frequency } \\
\text { Average }\end{array}$ & $\begin{array}{l}\text { Total } \\
\text { Frequency } \\
\text { Average }\end{array}$ \\
\hline $21-30$ years & 19 & 5 & 24 \\
& 1,42 & 1,80 & 1,50 \\
\hline $31-40$ years & 33 & 5 & 38 \\
& 1,30 & 2,00 & 1,39 \\
\hline $40+$ years & 9 & 1 & 10 \\
& 1,22 & 2,00 & 1,30 \\
\hline $\begin{array}{l}\text { Total } \\
\text { Frequency } \\
\text { Average }\end{array}$ & $\mathbf{6 1}$ & $\mathbf{1 1}$ & $\mathbf{7 2}$ \\
\hline
\end{tabular}

Table 7: Age, marital status and family structure

Table 7 shows the following tendency: young, married health professionals are more likely to live in nuclear families than older health professionals. This tendency is not confirmed by the chi-square statistic $(0.9194 ; \mathrm{df}=2 ; \mathrm{p}=.631$. This result is not significant at $\mathrm{p}<.01)$. 


\section{International Journal of Medical Science and Health Research}

Vol. 5, No. 01; 2021

ISSN: 2581-3366

\subsection{Relations between dependent variables}

The dependent variables in this research are the duration of the disease as a result of COVID-19, the total number of COVID-19 symptoms and anxiety for COVID-19 before and during the lockdown. A disease or medical condition that is simultaneously present with COVID-19 (comorbidity), is present at $7 \%(\mathrm{n}=5)$ of the healthcare professionals who fell ill because of COVID19. Co-morbidity can be considered as a covariate.

The seventh research question is: 'are there relations between the duration of the disease, the total number of symptoms, and anxiety (yes $=1$ and $2=$ no) during COVID-19 (before and during lock-down)?'

\begin{tabular}{|c|c|c|c|c|c|c|}
\hline $\begin{array}{l}\text { Number of } \\
\text { symptoms/ } \\
\text { Duration of } \\
\text { Illness }\end{array}$ & $\begin{array}{l}\mathbf{1} \\
\text { Freq } \\
\text { (average } \\
\text { anxiety }\end{array}$ & $\begin{array}{l}\mathbf{2} \\
\text { Freq } \\
\text { (average } \\
\text { anxiety }\end{array}$ & $\begin{array}{l}\mathbf{3} \\
\text { Freq } \\
\text { (average } \\
\text { anxiety }\end{array}$ & $\begin{array}{l}\mathbf{4} \\
\text { Freq } \\
\text { (average } \\
\text { anxiety }\end{array}$ & $\begin{array}{l}\mathbf{5} \\
\text { Freq } \\
\text { (average } \\
\text { anxiety }\end{array}$ & $\begin{array}{l}\text { Total } \\
\text { Freq } \\
\text { (average } \\
\text { anxiety }\end{array}$ \\
\hline $\begin{array}{l}\text { 10-14 days } \\
\text { (1) }\end{array}$ & $\begin{array}{l}8 \\
1,63\end{array}$ & $\begin{array}{l}12 \\
1,17\end{array}$ & $\begin{array}{l}17 \\
1,24\end{array}$ & $\begin{array}{l}5 \\
1,40\end{array}$ & $\begin{array}{l}0 \\
0\end{array}$ & $\begin{array}{l}42 \\
1,31\end{array}$ \\
\hline $\begin{array}{l}\text { 14-21 days } \\
\text { (2) }\end{array}$ & $\begin{array}{l}1 \\
1,00\end{array}$ & $\begin{array}{l}2 \\
1,00\end{array}$ & $\begin{array}{l}7 \\
1,43\end{array}$ & $\begin{array}{l}9 \\
1,11\end{array}$ & $\begin{array}{l}0 \\
0\end{array}$ & $\begin{array}{l}19 \\
1,21\end{array}$ \\
\hline $\begin{array}{l}>21 \text { days } \\
\text { (3) }\end{array}$ & $\begin{array}{l}0 \\
0\end{array}$ & $\begin{array}{l}1 \\
1,00\end{array}$ & $\begin{array}{l}0 \\
0\end{array}$ & $\begin{array}{l}7 \\
1,29 \\
\end{array}$ & $\begin{array}{l}3 \\
1,00\end{array}$ & $\begin{array}{l}11 \\
1,18\end{array}$ \\
\hline Total & $\begin{array}{l}9 \\
1,56\end{array}$ & $\begin{array}{l}15 \\
1,13\end{array}$ & $\begin{array}{l}24 \\
1,29\end{array}$ & $\begin{array}{l}21 \\
1,24\end{array}$ & $\begin{array}{l}3 \\
1,00\end{array}$ & $\begin{array}{l}72 \\
1,26\end{array}$ \\
\hline
\end{tabular}

Table 8: Duration of illness, number of symptoms and anxiety before and during the COVID-19 lockdown.

The outcomes are (chi-square: 38,$462 ; \mathrm{df}=8 ; \mathrm{p}=00000618$ ):

1. Healthcare professionals who are ill for 10-14 days by COVID-19, have less fear of COVID19 than healthcare professionals who are ill for longer by COVID-19.

2. Healthcare professionals with one symptom (including asymptomatic) have more anxiety about COVID-19 than healthcare professionals with 2 to 5 symptoms.

\begin{tabular}{|l|l|l|l|}
\hline Duration of illness & $\mathbf{N}$ & $\begin{array}{l}\text { Average } \\
\text { comorbidity }\end{array}$ & $\begin{array}{l}\text { Variance } \\
\text { comorbidity }\end{array}$ \\
\hline $10-14$ days & 42 & 1,93 & 0,07 \\
\hline $14-21$ days & 19 & 1,89 & 0,10 \\
\hline$>21$ days & 11 & 2,00 & 0,00 \\
\hline Total & $\mathbf{7 2}$ & $\mathbf{1 , 9 3}$ & $\mathbf{0 , 0 7}$ \\
\hline
\end{tabular}

Table 9: Duration of illness and comorbidity 


\section{International Journal of Medical Science and Health Research}

Vol. 5, No. 01; 2021

ISSN: 2581-3366

Table 9 examines the relationship between duration of illness by COVID-19 and comorbidity present. As a result, healthcare professionals with a disease or medical condition before COVID19 strikes are sick for almost as long as healthcare professionals without such a disease or medical condition (independent $\mathrm{T}$ test $=1,786 ; \mathrm{df}=70 ; \mathrm{p} \geq 0.05$ ).

\subsection{Prevention and dependent variables}

Variables indicating attempts to prevent COVID-19 (prevention) are information (attending a COVID-19 information session) and PPE (personal protective equipment). The WHO produced PPE guidelines ${ }^{10}$. Of the 72 healthcare professionals with COVID-19, 17 people (24\%) attended an information session on COVID-19.

\begin{tabular}{|l|l|l|l|}
\hline $\begin{array}{l}\text { Duration of } \\
\text { illness }\end{array}$ & $\mathbf{N}$ & $\begin{array}{l}\text { Average COVID-19 } \\
\text { sessions } \\
\text { (frequency: yes = 1) }\end{array}$ & $\begin{array}{l}\text { Standard deviation } \\
\text { COVID-19 sessions } \\
\text { (frequency: yes = 1) }\end{array}$ \\
\hline $10-14$ days & 42 & $\begin{array}{l}1,74 \\
\mathrm{n}=11(26 \%)\end{array}$ & 0,45 \\
\hline $14-21$ days & 19 & $\begin{array}{l}1,79 \\
\mathrm{n}=4(21 \%)\end{array}$ & 0,42 \\
\hline$>21$ days & 11 & $\begin{array}{l}1,82 \\
\mathrm{n}=2(18 \%)\end{array}$ & 0,40 \\
\hline Total & $\mathbf{7 2}$ & $\begin{array}{l}\mathbf{1 , 7 6}(\mathbf{2 4 \%}) \\
\mathbf{n = 1 7}\end{array}$ & $\mathbf{0 , 4 3}$ \\
\hline
\end{tabular}

Table 10: Duration of illness and attending an information session on COVID-19

The conclusion from these data in table 10 is that the information sessions on COVID-19 have no effect on the duration of the COVID-19 disease (chi-square $=0.404 ; \mathrm{df}=2 ; \mathrm{p}$-value $=0.817$ ).

\begin{tabular}{|l|l|l|l|l|}
\hline $\begin{array}{l}\text { Sum of PPE/ } \\
\text { Duration of } \\
\text { Illness }\end{array}$ & $\begin{array}{l}\mathbf{1 0 - 1 4} \text { days } \\
(\mathbf{n}=\mathbf{4 2})\end{array}$ & $\begin{array}{l}\mathbf{1 4 - 2 1} \text { days } \\
(\mathbf{n}=\mathbf{1 9})\end{array}$ & $\begin{array}{l}>\mathbf{2 1} \text { days } \\
(\mathbf{n}=\mathbf{1 1})\end{array}$ & $\begin{array}{l}\text { Total } \\
(\mathbf{n}=\mathbf{7 2})\end{array}$ \\
\hline $\mathbf{1}$ & 8 & 1 & 5 & $\mathbf{1 4}$ \\
\hline $\mathbf{2}$ & 14 & 7 & 1 & $\mathbf{2 2}$ \\
\hline $\mathbf{3}$ & 12 & 9 & 3 & $\mathbf{2 4}$ \\
\hline $\mathbf{4}$ & 3 & 2 & 0 & $\mathbf{5}$ \\
\hline $\mathbf{5}$ & 4 & 0 & 2 & $\mathbf{6}$ \\
\hline $\mathbf{6}$ & 1 & 0 & 0 & $\mathbf{1}$ \\
\hline Total & $\mathbf{4 2}$ & $\mathbf{1 9}$ & $\mathbf{1 1}$ & $\mathbf{7 2}$ \\
\hline
\end{tabular}

Table 11: sum of PPE and duration of illness

\footnotetext{
${ }^{10}$ https://www.who.int/teams/health-product-and-policy-standards/access-to-assistive-technology-medicaldevices/priority-medical-devices-for-covid/ppe-covid
} 


\section{International Journal of Medical Science and Health Research}

Vol. 5, No. 01; 2021

ISSN: 2581-3366

To avoid empty cells, columns 2 and 3 and rows 4,5 and 6 in Table 11 have been merged. The proportion of health professionals who reported one or more PPE did not differ by illness duration. $\mathrm{X}^{2}(1, \mathrm{n}=72)=1,29$, $\mathrm{p}$-value $\left.=0.731\right)$. This result is not significant at $\mathrm{p}<.05$.

\subsection{Recovery}

The variables used to measure recovery after healthcare professionals became ill as a result of COVID-19, are: a) the place of isolation (at home $(\mathrm{n}=56,78 \%)$ or isolation centre/ hospital $(\mathrm{n}=$ $16,22 \%)$ ), b) the use of ventilators (yes $=100 \%)$, c) use of medication (chloroquine ( $\mathrm{n}=2,3 \%)$; antibiotics $(\mathrm{n}=5,7 \%)$; no medicines $(\mathrm{n}=8,11 \%)$; and chloroquine + antibiotics $(\mathrm{n}=56,78 \%)$ ), d) don't have to work in the hospital (20-30 days $(\mathrm{n}=57,79 \%),>30$ days $(\mathrm{n}=8,11 \%)$ and no rest $(\mathrm{n}=7,10 \%))$, e) local administrative support $(\operatorname{good}(\mathrm{n}=16,22 \%)$, very good $(\mathrm{n}=5,7 \%)$, excellent $(\mathrm{n}=26,36 \%)$, satisfactory $(\mathrm{n}=4,6 \%)$ and non-satisfactory $(\mathrm{n}=21,29 \%))$, and $\mathrm{f})$ administrative support of the district (good, $(\mathrm{n}=7,10 \%)$, very good, $(\mathrm{n}=5,7 \%)$, excellent $(\mathrm{n}=$ $7,10 \%)$, satisfactory $(\mathrm{n}=15,21 \%)$ and non-satisfactory, $\mathrm{n}=38,53 \%)$ ).

The main outcomes that can be related to the recovery of healthcare professional's workers after they became ill due to COVID-19 are: a) home isolation (78\%), b) use of ventilators (100\%), c) use of chloroquine and antibiotics (78\%), and d) 20-30 days no hospital work (79\%). In addition, these sick healthcare professionals have had good local administrative support (64\%: good to excellent) and are poorly supported by the district (53\%: not satisfied). Insufficient support is referred to as secondary victimization (Steinmetz, 1990). Secondary victimization is distinguished from primary victimization. Primary victimization is becoming ill from COVID-19 and secondary victimization is, for example, being inadequately supported. Victims experience secondary victimization as a second wound.

\begin{tabular}{|l|l|l|l|}
\hline $\begin{array}{l}\text { Duration of Illness/ } \\
\text { Isolation }\end{array}$ & Home & $\begin{array}{l}\text { Isolation centre/ } \\
\text { hospital }\end{array}$ & Total \\
\hline $10-14$ days & $32(76 \% /$ & $10(24 \% /$ & $\mathbf{4 2}(\mathbf{1 0 0} \% /$ \\
$67 \%)$ & $63 \%)$ & $\mathbf{5 8 \%})$ \\
\hline $14-21$ days & $15(79 \% /$ & $4(21 \% /$ & $\mathbf{1 9}(\mathbf{1 0 0} \% /$ \\
& $27 \%)$ & $25 \%)$ & $\mathbf{2 6 \%})$ \\
\hline$>21$ days & $9(82 \% /$ & $2(18 \% /$ & $\mathbf{1 1}(\mathbf{1 0 0 \% /}$ \\
& $16 \%)$ & $12 \%)$ & $\mathbf{1 5 \%})$ \\
\hline Total & $\mathbf{5 6 ( 7 8 \% /}$ & $\mathbf{1 6}(\mathbf{2 2 \%} /$ & $\mathbf{7 2}(\mathbf{1 0 0} \% /$ \\
& $\mathbf{1 0 0 \% )}$ & $\mathbf{1 0 0 \% )}$ & $\mathbf{1 0 0 \% )}$ \\
\hline
\end{tabular}

Table 12: Duration of Illness and place of Isolation

This table shows that home isolation for healthcare professionals is most common and often lasts 10-14 days (78\%) [chi-square $0.18, \mathrm{df}=2$ and $\mathrm{p}$-values $=0.91$ ]. Moreover, this table shows that an illness duration of more than 21 days is relatively rare and that duration of illness in general is hardly influenced by where healthcare professionals go into isolation, at home or in hospital after becoming sick as a result of COVID-19. 


\section{International Journal of Medical Science and Health Research}

Vol. 5, No. 01; 2021

ISSN: 2581-3366

\begin{tabular}{|l|l|l|l|l|}
\hline $\begin{array}{l}\text { Type of } \\
\text { medication/ } \\
\text { Duration of } \\
\text { Illness }\end{array}$ & No medicine & $\begin{array}{l}\text { chloroquine or } \\
\text { antibiotics }\end{array}$ & $\begin{array}{l}\text { Chloroquine } \\
\text { and } \\
\text { antibiotics }\end{array}$ & Total \\
\hline $\mathbf{1 0 - 1 4}$ days & $6(14 \%)$ & $4(10 \%)$ & $32(76 \%)$ & $\mathbf{4 2 ( 1 0 0 \% )}$ \\
\hline $\begin{array}{l}\mathbf{1 4 - 2 1} \text { days }+ \\
\text { more than 21 } \\
\text { days }\end{array}$ & $2(6 \%)$ & $3(9 \%)$ & $25(78 \%)$ & $\mathbf{3 2 ( 1 0 0 \% )}$ \\
\hline Total & $\mathbf{8 ( 1 1 \% )}$ & $\mathbf{7 ( 1 0 \% )}$ & $\mathbf{5 7}(\mathbf{7 9 \%})$ & $\mathbf{7 2 ( 1 0 0 \% )}$ \\
\hline
\end{tabular}

Table 13: Duration of illness and type of medicine

The outcome of table 13 is that there are no relations between medication (none, 1 or 2 ) and the duration of the disease by COVID-19. See: chi-square $=1.031$, $\mathrm{df}=2, \mathrm{p}$-value $=0.60$, Yates' chi-square $=0.5$ and Yates 'p-value $=0.78$.

\subsection{Effects: physical and psychological}

The variables used to measure effects of COVID-19 among healthcare professionals, are a) spread to others (yes $=28,39 \%$; no $=44,61 \%$ ), b) effect on health system $(y e s=62,86 \%$; no = $10,14 \%)$, c) feeling unsafe among family (yes $=63,88 \%$; no $=9,12 \%$ ), d) fear after COVID-19 recovery $($ yes $=54,75 \%$; no $=18,25 \%$ ), and e) fear of others after recovery $($ mostly $=52,72 \%$; some $=13,18 \%$ and none $=7,10 \%)$.

A remarkable outcome is the spread of COVID-19 by sick healthcare professionals to others. Almost two-fifths of healthcare professionals have experienced this.

Thirdly, the psychological consequences of COVID-19 among healthcare professionals are considerable. This is deduced from feeling unsafe among family (88\%), fear after COVID-19 recovery $(75 \%)$, and fear of others after recovery from COVID-19 (72\%).

\subsection{Long term consequences and giving back}

Of all healthcare professionals who became ill as a result of COVID-19, 94\% have an antibody $(\mathrm{n}=68)$ and 8 people $(\mathrm{n}=6)$ have donated plasma.

\section{Conclusions}

The results of the descriptive framework are listed below.

One of the most notable research results related to sick healthcare professionals by COVID-19 at the DHQ Timergara teaching hospital in Khyber Pakhtunkhwa Province, Pakistan, is the phenomenal decline of $36 \%$ in 'normal' patient care in virtually all departments of the hospital. The care of patients with COVID-19 displaces the 'normal' patient care.

Most healthcare professionals have become infected in hospital (97\%), so infection at home of healthcare professionals is almost non-existent. $11 \%$ of all healthcare professionals in this hospital tested positive with a RT-PCR test. This study $(\mathrm{n}=72)$ shows that nurses $(30 \%)$ in 


\section{International Journal of Medical Science and Health Research}

Vol. 5, No. 01; 2021

ISSN: 2581-3366

particular are more often victims of COVID-19 than doctors (19\%) and other paramedical professions (3\%). Mainly male healthcare professionals (72\%) are victims of COVID-19, more so than female healthcare professionals (28\%). This result may be due to the fact that more men than women work in this hospital. During COVID-19 nurses are just as anxious about COVID19 as doctors.

Thirdly, this research on COVID-19 victims among healthcare professionals in this hospital in Khyber Pakhtunkhwa-Pakistan has revealed the following: a) victim prone places in this hospital for COVID-19 are emergency, labour rooms and COVID treatment rooms, b) on average, female healthcare professionals $(\overline{\mathbf{x}}=1,60)$ are sick for as long as male healthcare professionals $(\overline{\mathbf{x}}=$ 1,56) after they fall ill as a result of COVID-19 and, and c) female healthcare professionals have as many COVID-19 symptoms as male healthcare professionals (independent $\mathrm{T}$ test $=1.226$; $\mathrm{df}$ $=702 ; \mathrm{p} \leq 0.20$ ).

Fourth, on average, doctors are sick longer than nurses (independent T-test $=1.79 ; \mathrm{df}=58 ; \mathrm{p}=$ 0.05). Doctors and nurses, on the other hand, have on average the same number of COVID-19 symptoms (independent T-test $=0.592 ; \mathrm{df}=58 ; \mathrm{p}>0.09$ ). During COVID-19 doctors are as anxious as nurses for COVID-19 during COVID-19 (independent T-test $=0.768$; $\mathrm{df}=58 ; \mathrm{p}=$ 0.5 ). Healthcare professionals from a nuclear family have more symptoms than healthcare professionals from extended families (independent T-test $=11.38 ; \mathrm{df}=10 ; \mathrm{p}<.001$ ).

\subsection{Relations between dependent variables}

The relationship between the duration of the disease due to COVID-19 and anxiety during COVID-19 is described in the following results (chi-square: 38,$462 ; \mathrm{df}=8 ; \mathrm{p}=00000618$ ): a) healthcare professionals who have been ill for longer are less afraid of COVID-19 than healthcare workers who have been ill for shorter periods and b) healthcare professionals with one symptom (incl. asymptomatic) are less afraid of COVID-19 than healthcare professionals with 2 up and including 5 symptoms.

Secondly, $7 \%$ of healthcare professionals have one or more other conditions or disorders (comorbidity) at the time they become ill due to COVID-19. Comorbidity has no effect on the duration of the disease.

Thirdly, the proportion of healthcare professionals, who reported one or more PPE's (personal protective equipment), did not differ by duration of illness, $X^{2}=1,29 ; \mathrm{df}=70 ; \mathrm{p}$-value $=0.731$ ). The result is not significant at $\mathrm{p}<.05$.

\subsection{Recovery}

The main outcomes that can be linked to the rehabilitation of healthcare professionals after they became ill due to COVID-19 are as follows: a) home isolation (78\%), b) use of ventilators $(100 \%)$, c) use of chloroquine and antibiotics (78\%), and d) 20-30 days of hospital rest (79\%). Furthermore, these sick healthcare professionals have had superb local administrative support (64\%: good to excellent) and are further worse supported by the district (53\%: not satisfied). Not 


\section{International Journal of Medical Science and Health Research}

Vol. 5, No. 01; 2021

ISSN: 2581-3366

supporting them sufficiently is also called secondary victimization (Steinmetz, 1990), inflicting a second wound.

Secondly, there is no relation between medication (none, 1 or 2) and the duration of the disease by COVID-19. See: chi-square $=1.031, \mathrm{df}=2, \mathrm{P}$-value $=0.60$, Yates' chi-square $=0.5$ and Yates 'p-value $=0.78$.

\subsection{Effects: physical and psychological}

According to the healthcare professionals who became ill as a result of COVID-19, the following effects have become visible: a) spread to others (yes $=39 \%$ ), effect on health system (yes = $86 \%$ ), feeling unsafe among family (yes $=88 \%$ ), fear after COVID-19 recovery (yes $=75 \%$ ), and fear of others after recovery (mostly $=72 \%$ ).

\subsection{Long-term consequences and giving back}

Of all healthcare professionals who became ill as a result of COVID-19, 68 have an antibody (94\%) and 6 people (11\%) have donated plasma.

\section{Interpretation of the findings and discussion}

This research among healthcare professionals on COVID-19 at the training hospital in Khyber Pakhtunkhwa, Pakistan creates a descriptive framework based on a cross-sectional study.

A theory of infection was postulated earlier in this article. It is called the opportunity theory. To put it simply, this theory boils down to the following: the COVID-19 virus is looking for opportunities to strike. A concrete exposure to virus particles can also be called opportunity. Although this has not been proven, the aim of the COVID-19 virus particles seems to be to multiply as much as possible. This objective can be achieved by infecting as many people and animals as possible and implementing infecting as effectively as possible so that the end result is as many virus particles as possible. That works better if the opportunity increases (for example, many infected and non-infected people together in a poorly ventilated area), if there is hardly any prevention (protective clothing and social distance of at least 1,5 meter). Finally, the virus particles are more successful if healthcare professionals already have one or more disruptive health conditions (like diabetes or possible heart failure) or psychiatric disorders.

What does this research show? Firstly, COVID-19 has an enormous effect on health care deliveries now and in the future. Now because regular patients are being ousted by COVID-19 patients. Also $86 \%$ of healthcare professionals indicate that COVID-19 has an effect on healthcare now and in the future. Secondly, $11 \%$ of the total hospital population gets COVID-19 and becomes ill. Thirdly, that nurses are the group most at risk (30\%) by COVID-19. The second at-risk group are doctors (19\%) and the third paramedical professions (3\%). A striking fourth result is that doctors are sick for longer than nurses but otherwise have as many symptoms as nurses. Furthermore, this research shows that co-morbidity is not related to the disease duration of healthcare professionals. In conclusion, this study shows that the psychological symptoms, especially anxiety symptoms, are additional effects of the COVID-19 disease caused by the virus 


\section{International Journal of Medical Science and Health Research}

Vol. 5, No. 01; 2021

ISSN: 2581-3366

particles. These are anxiety complaints during this entire COVID-19 period (during and after the disease), fear of infecting family members and fear of becoming infected again.

Are there other studies in the world that find similar, lower or higher COVID-19 disease rates among healthcare professionals detected by a RT-PCR test?

"A study in New York (United States) among healthcare professionals (total 617 employees) comes with a higher figure, namely 29.8\%. The differences between hospital departments here are large (significant: $\mathrm{p}<.05$ ). The RT-PCR test in this hospital shows the highest positive results at the workplace (42.3\%), operating theatre $(32.3 \%)$ and emergency department (31.4\%) according to Jeremias et al. 2020".

A study in Brazil on COVID-19 among healthcare workers in a public hospital in the city of Santos, Brazil gives the following results (Caseiro et al., 2020):

“211 (16.1\%) of the Hospital's employees (1307 employees) had to stop their work-related activities due to presenting positive RT-PCR. There were 39 (9.9\%) positives in low risk areas and $172(18.8 \%)$ positives in employees in high risk areas. Within the latter group, Nurses, Nursing Assistants and Doctors were the most frequently infected professionals. Regarding the symptoms of professionals positively diagnosed based on RT-PCR, the most frequent symptoms were body pain $(83.4 \%)$; headache $(80.6 \%)$; fever $(57.8 \%)$ and dry cough $(53.1 \%) . "$

These results on RT-PCR tests show that there is a ranking, number one is the hospital in New York of the United States of America, number two is the hospital in Santos-Brazil and number three is the hospital in Khyber Pakhtunkhwa-Pakistan (chi-square is 52.97. The p-value is $<.00001$. The result is significant at less then 0.001).

All data on COVID-19 virus in these studies are indirect data. To really test the opportunity theory, we need direct data, such as how many virus particles are effective when they attack humans or animals, at what rate (hour to hour, minute to minute and second to second) the human or animal body then becomes infected with virus particles and under what circumstances these virus particles cause direct and/or indirect symptoms of illness, which they are and when they become a danger to their fellow humans or animals. In other words, by gaining a better understanding of how the contamination with COVID-19 particles occurs and how it can lead to COVID-19 disease, we as social scientists can better consider which questions and measurements are relevant to gain insight into the contamination with COVID-19 particles and diseases caused by COVID-19. This will also give us a better understanding of which protective and curative measures work.

What can be measured indirectly is the number of people infected by a person who is already infected. A standard period of 4 days is used for this. This number is also called the reproduction 


\section{International Journal of Medical Science and Health Research}

Vol. 5, No. 01; 2021

ISSN: 2581-3366

number, $\mathrm{R}^{11}$. With an $\mathrm{R}>1$ the number of infected people increases and with an $\mathrm{R}<1$ the number of infected people decreases.

A critical note is in order when postulating the opportunity theory because the damage that COVID-19 causes to individuals and groups of people is not only physical but also psychological. After all, the physical damage can be directly traced back to the virus particles, but the same may not be true of the psychological damage. Also because no research has been done into this.

Support for the opportunity theory in this Khyber Pakhtunkhwa study is the number of healthcare professionals at certain workplaces felled by COVID-19. Victim prone places for COVID-19 in this hospital are emergency (29\%), labour room (19\%) and COVID treatment rooms (15\%). Another support for the opportunity theory is that nurses are more at risk of COVID-19 disease than doctors. Although this has not been measured, we could call this the exposure (= contact) opportunity hypothesis for the COVID-19 particles as part of the opportunity theory. Nurses are at greater risk than doctors, as they see patients for longer periods and more often and also have to intubate their patients. This also applies to emergencies. Very sick patients may not yet be detected as a COVID-19 patient. There is however no support for preventive measures, such as information and protective measures. We can guess why this is so. After all, the better the protective measures are, the smaller the risk of infection and therefore disease. The protective measures may not be effective enough. which was mentioned earlier because at the beginning of the COVID-19 pandemic there was not enough protective material for health professionals, so the existing protective material had to be reused ${ }^{12}$. Another source of support for the opportunity theory is that measures (such as medication) to recover are not related to the duration of the disease. Our hypothesis is that sick healthcare professionals can infect others, presumably other colleagues, as a result of this, without wanting to do so.

Finally, this Pakistani study in its training hospital in Khyber Pakhtunkhwa among healthcare professionals also shows the long-term results, namely of all healthcare professionals who became ill as a result of COVID-19, 68 (94\%) had an antibody (94\%) and 6 people (11\%) donated plasma. This percentage with antibody by COVID-19 seems high against the background of the US investigation in Orange County, California, see the following quote:

"A blood sample was collected from each subject for serum analysis for IgG antibodies to SARS-CoV-2. Of 2,992 tested individuals, a total 2,924 with complete data were included in the analysis. Observed prevalence of $1.06 \%$ (31 antibody positive cases), adjusted prevalence of $1.13 \%$ for test-sensitivity and specificity were identified."

\footnotetext{
${ }^{11}$ https://www.rivm.nl/en/novel-coronavirus-covid-19/modelling

12 "The coronavirus pandemic has created worldwide shortages of N95 respirators. We analyzed 4 decontamination methods for effectiveness in deactivating severe acute respiratory syndrome coronavirus 2 virus and effect on respirator function. Our results indicate that N95 respirators can be decontaminated and reused, but the integrity of respirator fit and seal must be maintained (Fisher et al. 2020)."
}

www.ijmshr.com

Page 140 


\section{International Journal of Medical Science and Health Research}

Vol. 5, No. 01; 2021

ISSN: 2581-3366

An important point of attention for the hospital is that healthcare professionals should be given more psychological attention. Possible methods to support health professionals psychologically are stress inoculation, i.e. before these healthcare professionals become ill inoculating them with a psychological COVID-19 vaccine, providing victim support during and after COVID-19 and providing EMDR therapy, if the healthcare professionals develop post-traumatic stress disorder symptoms as a result of COVID-19. A motive for insisting on psychological help and assistance is the knowledge that body and mind are one, and thus the mind can influence the body and the body in turn can influence the mind.

A final comment should not be missing from this discussion. A better research design could possibly provide more support for the theory of opportunity. An ideal study consists of follow-up measurements and also a comparison between healthcare professionals who became ill and those did not. In this way, we gain more insight into how the virus works. Finally, it is desirable to study the biological variables more in more detail so that we can determine in a social-scientific way how the virus particles behave in the same work floor where ventilation and thorough cleaning are always a problem.

\section{References}

Black J.R., Bailey C, Przewrocki J., Dijkstra K.K. \& Swanton C. (2020). COVID-19: the case for health-care worker screening to prevent hospital transmission. The Lancet. 2020 May 2;395(10234):1418-20. https://doi.org/10.1016/ S0140-6736(20)30917-X

Brant-Zawadzki, M., Fridman D., Robinson, P.A., Zahn M., Chau C. \& German R. (2020). SARS-CoV-2 antibody prevalence in health care workers: Preliminary report of a single center study. PLoS ONE 15(11): e0240006. https://doi.org/10.1371/journal.pone.0240006

Carter, P., Anderson M., \& Mossialos, E. (2020). Health system, public health, and economic implications of managing COVID-19 from a cardiovascular perspective. European Heart Journal. 2020 Apr 22. Doi: 10.1093/eurheartj/ehaa342

Caseiro, Marcos, Montani, Mazzurana, Monica, Barreiro, Bruno, Barbosa, Estela Capelas, Barbosa, \& Pires, Antônio (2020). Positivity of SARS-CoV-2, by RT-PCR among workers of a Public Hospital in the city of Santos, SP, Brazil 2020. medRXiv. BMJ Yale. The preprinter service for health sciences. Doi: https://doi.org/10.1101/2020.06.30.20143529. https://www.medrxiv.org/content/10.1101/2020.06.30.20143529v1.article-info

Chandir S., Siddiqi, D.A., \& Setayesh, H., Khan, A.J. (2020). Impact of COVID-19 lockdown on routine immunisation in Karachi, Pakistan. The Lancet Global Health. 2020 September 1;8(9):e1118-20. Doi: 10.1016/S2214-109X(20)30290-4

Elkholy, A.A., Grant, R., Assiri, A., Elhakim M., Malik, M.R. \& Kerkhoven, van, M.D. (2020). MERS-CoV infection among healthcare workers and risk factors for death: Retrospective analysis of all laboratory-confirmed cases reported to WHO from 2012 to 2 June 2018. 


\section{International Journal of Medical Science and Health Research}

Vol. 5, No. 01; 2021

ISSN: 2581-3366

Journal of infection and public health. 2020 Mar 1;13(3): 418-22. Doi: 10.1016/j.jiph.2019.04.011

Elm, von, E, Altman, D.G., Egger M., Pocock, S.J., Gøtzsche, P.C., \& Vandenbroucke J.P. (2007). The Strengthening the Reporting of Observational Studies in Epidemiology (STROBE) statement: guidelines for reporting observational studies. The Lancet. 2007 Oct 20; 370(9596):1453-7. Doi: https://doi.org/10.1016/S0140-6736(07)61602-X

Fischer, R.J., Morris, D.H., Doremalen, van, N., Sarchette, S., Matson M.J., Bushmaker, T., Yinda, C.K., Seifert, S.N., Gamble, A., Williamson, B.N., \& Judson, S.D. (2020). Effectiveness of N95 respirator decontamination and reuse against SARS-CoV-2 virus. Emerging infectious diseases. 2020 Sep;26(9):2253. Doi: 10.3201/eid2609.201524

Ghinai, I, McPherson, T.D., Hunter, J.C., Kirking, H.L., Christiansen, D., Joshi, K., Rubin, R, Morales-Estrada, S., Black, S.R., Pacilli, M., \& Fricchione, M.J. (2020). First known person-to-person transmission of severe acute respiratory syndrome coronavirus 2 (SARS-CoV-2) in the USA. The Lancet. 2020 March 13. Doi: 10.1016/S0140$\underline{6736(20) 30607-3}$

Haq, F.U., Roman, M, Ahmad, K., Rahman, S.U., Shah, S.M., Suleman, N., Ullah, S., Ahmad, I., \&Ullah, W. (2020). Artemisia annua: trials are needed for COVID-19. Phytotherapy Research. 2020 May 19. https://doi.org/10.1002/ptr.6733

Haq, F.U., Saleem, S., Imran, M., Ghazal, A, Ahmad, K., Roman, M., Rahman, S.U., Ullah, S., Ahmad, I., Mehmood, H., \& Ullah, W. (2020). Phylogenetic analyses and genomic variation of the 2019-nCoV. Journal of Pharmaceutical and Biopharmaceutical Research. 2020 Aug 24;2(1):126-30. https://doi.org/10.25082/JPBR.2020.01.004

Jones, D., S. (2020). History in a crisis-lessons for Covid-19. New England Journal of Medicine. 2020 Apr 30;382(18):1681-3. DOI: 10.1056/NEJMp2004361

Jeremias, Allen, Nguyen, James, \&Levine, Joseph (2020). Prevalence of SARS-CoV-2 Infection Among Health Care Workers in a Tertiary Community Hospital. JAMA Intern Med. 2020;180(12):1707-1709.

Doi:10.1001/jamainternmed.2020.4214 https://jamanetwork.com/journals/jamainternalmedicine/fullarticle/2769442?alert=article

Joseph, Bobby \& Joseph, Merlyn (2016). The health of the healthcare workers.Indian J Occup Environ Med. 2016 May-Aug; 20(2): 71-72. doi: 10.4103/0019-5278.197518. https://www.ncbi.nlm.nih.gov/pmc/articles/PMC5299814/

Kandel, N., Chungong, S., Omaar, A., \&Xing J. (2020). Health security capacities in the context of COVID-19 outbreak: an analysis of International Health Regulations annual report data from 182 countries. The Lancet. 2020 March 18. DOI: 10.1016/S01406736(20)30553-5

Keulemans, Maarten (20 December 2020). De Britse corona-mutant: zorgwekkend, of valt het wel mee? De Volkskrant, 20 December 2020; 13:39. 


\section{International Journal of Medical Science and Health Research}

Vol. 5, No. 01; 2021

ISSN: 2581-3366

Lancet The. Editorial. COVID-19: protecting health-care workers. Lancet (London, England). 2020 Mar 21;395 (10228):922. DOI: https://doi.org/10.1016/S0140-6736(20)30644-9. https://www.thelancet.com/journals/lancet/article/PIIS0140-6736(20)30644-9/fulltext

Mahmood, Qaisar, Khalid, Jafreem, Sara Rizvi, Jalil, Aisha, Hasnain Nadir, Syed, Mujtaba, \& Fischer, Florian (2021). Preprint. Anxiety amongst physicians during COVID-19:Crosssectional study in Pakistan. Research Square. DOI: https://doi.org/10.21203/rs.3.rs$\underline{51322 / \mathrm{v} 2}$

Nguyen, L.H., Drew, D.A., Graham, M.S., Joshi, A.D., Guo, C.G., Ma, W., Mehta, R.S., Warner, E.T., Sikavi D.R., Lo, C.H., \&Kwon S. (2020). Risk of COVID-19 among front-line health-care workers and the general community: a prospective cohort study. The Lancet Public Health. 2020 Sep 1;5(9):e475-83. doi: 10.1101/2020.04.29.20084111

Pal, Mahendra, Kerorsa, Berhanu, Gemechu, \& Venkataramana, Kandi (2020). A Knowledge Update on SARS-Coronavirus-2 (SARS-CoV-2)/COVID-19 and Its Global Public Health Implications. American Journal of Clinical Medicine Research, 2020, Vol. 8, No. 1, 2327 Available online at http://pubs.sciepub.com/ajcmr/8/1/5 Published by Science and Education Publishing DOI:10.12691/ajcmr-8-1-5

Peng†, Yi, Kou†, Gang, Kou, Shi Yong and Chen, Zhengxin (2008). A Descriptive Framework for the Field of Data Mining and Knowledge Discovery. International Journal of Information and Decision Making. Vol. 7, No. 4 (2008) 639-682. CWorld Scientific Publishing Company. DOI: $\quad$ 10.1142/S0219622008003204. RG: https://www.researchgate.net/publication/23751213 A Descriptive Framework for the Field of Data Mining and Knowledge Discovery

Voormolen, Sander (18 $8^{\text {th }}$ of December, 2020). Hoe twee dappere virologen de Chinese doofpot omzeilden. NRC.nl. https://www.nrc.nl/nieuws/2020/12/18/china-een-jaar-geleden-tweedappere-virologen-omzeilen-de-doofpot-a4024454

Steinmetz, Carl H.D. (1979). An empirically tested analysis of victimization risks. PAPER PRESENTED AT THE THIRD INTERNATIONAL SYMPOSIUM ON $\begin{array}{lll}\text { VICTIMOLOGY, } & \text { SEPTEMBER } & 3-7,\end{array}$ https://www.researchgate.net/publication/323389911 An empirically tested analysis of victimization risks

Steinmetz, Carl H.D. (1990). Hulp aan slachtoffers van misdrijven. Effecten van slachtofferhulp en primaire opvang. Onderzoek en Beleid, 98. Gouda Quint bv. https://www.researchgate.net/publication/289977150 Hulp aan slachtoffers van ernstig e misdrijven Effecten van slachtofferhulp en primaire opvang

Steinmetz, Carl Hermann Dino (2020). Covid-19, Superdiversity, Crisis-Communication and leadership: Lessons to be Learned. International Journal of Economics, Business and Management Research, Vol. 4, No. 06; 2020. ISSN: 2456- 
7760.https://www.researchgate.net/publication/342420443 COVID-

19_SUPERDIVERSITY_CRISIS-

COMMUNICATION_AND_LEADERSHIP_LESSONS_TO_BE_LEARNED

Verbeek, J.H., Rajamaki, B., Ijaz, S., Sauni, R., Toomey, E., Blackwood, B., Tikka C, Ruotsalainen, J.H., \& Balci, F.S. (2020). Personal protective equipment for preventing highly infectious diseases due to exposure to contaminated body fluids in healthcare staff. Cochrane Database of Systematic Reviews. 2020(4). doi: 10.1002/14651858.CD011621.pub4.

Wang, J., Zhou, M., \& Liu, F. (2020). Reasons for healthcare workers becoming infected with novel coronavirus disease 2019 (COVID-19) in China. J Hosp infect. 2020 Mar 6;105(1). DOI: 10.1016/j.jhin.2020.03.002

Ziarati, Parisa, Sultan, Amina, Kamyab-Moghadas, Bahareh, Shirkhan, Faezeh, Cruz Rodriguez, Luis and Juneja, Akanksha (2020). An insight into the prevailing trends of self-immunity and lifestyle in protection from Covid-19 amongst the health care workers. J Med Discov (2020); 5(4):jmd20065; DOI:10.24262/jmd.5.4.20065

Zhu, N., Zhang, D., Wang, W., Li, X., Yang, B., Song, J., Zhao, X., Huang, B., Shi, W, \& Lu R, Niu, P. (2020). A novel coronavirus from patients with pneumonia in China, 2019. New England Journal of Medicine. 2020 Jan 24. DOI: 10.1056/NEJMoa2001017 